\title{
Respon Histologis Hepar Tikus Wistar yang Mengalami Stres Fisiologis setelah Pemberian Pakan dengan Suplementasi Daging Ikan Gabus (Channa striata)
}

\section{Histologic Response of Wistar Worm Rats Due to Physiological Stress after Feeding with Snake Head Fish Meat Supplement (Channa striata)}

\author{
Beta Cahyaning Nugraheni ${ }^{1 *}$, Sunarno $^{2}$, Siti Muflichatun Mardiati ${ }^{2}$ \\ ${ }^{1}$ Mahasiswa Departemen Biologi, Fakultas Sains dan Matematika, Universitas Diponegoro \\ ${ }^{2}$ Departemen Biologi, Fakultas Sains dan Matematika, Universitas Diponegoro \\ Jl. Prof. Soedarto, SH, Tembalang, Semarang \\ *Email : betacahyaningn@gmail.com
}

Diterima 30 Juli 2018 / Disetujui 8 Oktober 2018

\begin{abstract}
ABSTRAK
Stres fisiologis karena kekurangan nutrisi yang disertai aktivitas berlebihan dapat menyebabkan kekurangan energi yang dibutuhkan oleh tubuh. Kekurangan energi dapat berpengaruh pada penurunan bobot badan, bobot dan histologi hepar. Penelitian ini dilakukan untuk menganalisis pengaruh suplemen daging ikan gabus terhadap peningkatan bobot badan, bobot dan histologi hepar hewan uji yang mengalami stres fisiologis. Penelitian ini terdiri atas 5 perlakuan dan 4 kali ulangan. Perlakuan pada penelitian ini terdiri atas P0: tikus kontrol; P1, P2, P3, dan P4 berturut-turut adalah: suplemen daging ikan gabus dalam pakan dengan konsentrasi 5\%; 10\%; 15\%; dan 20\%. Penelitian ini menggunakan Rancangan Acak Lengkap (RAL). Variabel yang diukur pada penelitian ini adalah bobot badan, bobot hepar, diameter vena sentralis dan hepatosit. Data dianalisis menggunakan Analysis of Variance (ANOVA) dan dilanjutkan dengan uji Duncan dengan signifikansi 5\%. Hasil analisis data menunjukkan suplemen daging ikan gabus memberi pengaruh nyata terhadap bobot badan, bobot dan histologi hepar. Suplemen daging ikan gabus mampu meningkatkan bobot badan, bobot hepar, dan histologi hepar yang ditunjukkan dengan nilai diameter vena sentralis dan hepatosit lebih tinggi dibanding kontrol. Kesimpulan penelitian ini yaitu suplemen daging Channa striata dapat meningkatkan bobot badan, bobot hepar, diameter vena sentralis, dan hepatosit tikus Wistar dan konsentrasi $20 \%$ paling berpengaruh.
\end{abstract}

Kata kunci : Stres fisiologis, bobot badan, tikus Wistar, bobot hepar, vena sentralis, hepatosit

\begin{abstract}
Physiological stress due to lack of nutrition accompanied by excessive activity can cause a lack of energy needed by the body. Energy deficiency can affect the decrease in body weight, weight and histology of the liver. This research was conducted to analyze the effect of snakehead fish supplement on increasing body weight, weight and liver histology that experienced physiological stress. This study consisted of 5 treatments and 4 repetitions. The treatment in this study consisted of P0: control; P1, P2, P3, and P4 respectively: snakehead fish meat supplement in the diet at levels of $5 \% ; 10 \% ; 15 \%$; and $20 \%$. This study uses a Completely Randomized Design. Data were analyzed using Analysis of Variance and Duncan test with a significance of 5\%. The results of data analysis showed that supplementation of snakehead fish meat had a significant effect on body weight, weight and histology of the liver. Snakehead fish meat supplement can increase body weight, liver weight, and liver histology as indicated by the central venous and hepatocyte diameter values higher than controls. The conclusion of this study is that Channa striata meat supplement can increase body weight, liver weight, central venous diameter, and hepatocytes and the most influential $20 \%$ concentration.
\end{abstract}

Keywords : Physiological stress,body weight, wistar rat, hepar weight, central vein, hepatocyte 


\section{PENDAHULUAN}

Penurunan bobot badan dan gangguan hepar merupakan masalah utama kesehatan bagi hewan. Kasus ini banyak terjadi pada hewan yang mengalami stres fisiologis. Hepar sangat berpotensi mengalami penurunan bobot dan gangguan karena merupakan salah satu organ yang rentan terhadap stres fisiologis. Stres fisiologis karena kekurangan nutrisi yang disertai aktivitas berlebihan dapat memicu peningkatan produksi radikal bebas, gangguan keseimbangan hormonal dan menyebabkan permasalahan kekurangan energi yang dibutuhkan oleh tubuh. Radikal bebas, gangguan regulasi metabolisme oleh hormon, dan kekurangan energi ini dapat menimbulkan gangguan histopatologi hepar (Silva et al., 2015).

Gangguan hepar dapat memicu terjadinya degenerasi hepatosit. Gangguan tersebut dapat disebabkan oleh faktor defisinsi pakan, hipoksia yang berkepanjangan, intoksikasi dan penuaan jaringan. Degenerasi sel hepar apabila tidak tertangani dapat memicu terjadinya nekrosis hepatosit (Suarsana et al., 2013).

Gangguan pada organ hepar dapat diperbaiki dan ditingkatkan fungsinya (Charlton, 2006). Perlakuan untuk pemulihan histopatologi hepar pada prinsipnya adalah pemeliharaan keseimbangan hormonal, peningkatan antioksidan dalam tubuh, menjamin ketersediaan nutrisi yang dibutuhkan oleh tubuh untuk mendukung proses metabolisme yang berorientasi pada produk energi, dan pembentukan jaringan baru (Silva et al., 2015). Berbagai macam pilihan suplemen pakan telah dikenal oleh masyarakat untuk mendukung perbaikan histopatologi hepar. Salah satu cara kerja suplemen pakan adalah menjamin ketersediaan nutrisi yang dapat mendukung perbaikan jaringan hepar, seperti albumin, glutamin, sistein, dan glisin (Chotechuang, 2010).

Indonesia memiliki sumber daya alam perikanan air tawar yang tersebar luas. Berbagai macam jenis ikan, baik yang hidup liar di alam maupun yang dibudidayakan terdapat dalam jumlah yang cukup banyak, salah satunya adalah ikan gabus. Pencarian suplemen pakan yang berasal dari ikan air tawar banyak dilakukan oleh para peneliti. Ikan air tawar telah diketahui banyak mengandung senyawa bioaktif atau nutrisi esensial seperti albumin, glutamin, sistein, dan glisin. Suplemen pakan yang memiliki potensi seperti ini misalnya bersumber dari daging ikan gabus atau Channa striata (Ningrum dan Abdulgani, 2014).

Hasil penelitian Aisyatussoffi dan Abdulgani (2013) menunjukkan bahwa kandungan protein dalam daging ikan gabus adalah $25,2 \%$ dan $6,2 \%$ dari protein tersebut berupa albumin. Daging ikan gabus memiliki kandungan protein dan bermanfaat untuk memperbaiki sel-sel tubuh yang rusak. Ningrum dan Abdulgani (2014) menyatakan, ikan gabus merupakan sumber albumin dan jenis protein ini mempunyai korelasi positif dengan aktivitas antioksidan yang berfungsi untuk melindungi jaringan tubuh dari kerusakan oleh radikal bebas akibat stres fisiologis. Albumin merupakan protein yang merupakan rantai tunggal polipeptida dengan berat molekul 66,4 $\mathrm{kDa}$ dan terdiri dari 585 asam amino. Molekul albumin memiliki gugus sulfhidril (-SH) yang dapat berfungsi sebagai pengikat radikal, sehingga albumin dapat berfungsi sebagai antioksidan. Sunarno et al. (2015) menyatakan bahwa dalam setiap 100g daging ikan gabus mengandung $32,39 \%$ glutamin, $6,61 \%$ sistein, dan $9,69 \%$ glisin. Protein dan asam-asam amino seperti glutamin, sistein, dan glisin telah diketahui memiliki peran penting dalam memperbaiki jaringan tubuh yang mengalami penurunan fungsi akibat stres fisiologis (Sunarno et al., 2013).

Penelitian ini bertujuan untuk mengkaji dan menganalisis pengaruh suplemen daging ikan gabus dalam pakan terhadap peningkatan bobot badan, peningkatan bobot hepar, dan perbaikan histopatologi hepar, serta untuk mendapatkan profil histologis hepar tikus setelah pemberian pakan dengan suplementasi daging ikan gabus pada hewan uji yang mengalami stres fisiologis.

\section{METODE PENELITIAN}

Penelitian dilaksanakan di Laboratorium Biologi Struktur dan Fungsi Hewan, Departemen Biologi, Fakultas Sains dan Matematika, Universitas Diponegoro, Semarang. Waktu penelitian akan dilaksanakan pada bulan November 2016 hingga bulan Februari 2017. 
Bahan yang digunakan antara lain ikan gabus yang berasal dari Rawa Pening, tikus putih wistar jantan, sekam padi, air minum, pakan tikus, garam fisiologis ( $\mathrm{NaCl} 0,95 \%)$, akuades, larutan Bouin, dan BNF 10\%. Alat - alat yang digunakan antara lain kandang hewan uji, tempat pakan, tempat minum, seperangkat alat bedah (dissecting set), stopwatch, penggiling pakan (grinder), blender, timbangan analitik, inkubator, nampan plastik, kawat ram, ember volume 25 liter, erlenmeyer, gelas beaker, pemanas air, cawan petri, kapas, tisu, sarung tangan, dan masker.

Prosedur pembuatan suplemen pakan dari daging ikan gabus diawali dengan pemotongan bagian badan yang dipisahkan dengan bagian kepala dan ekor. Daging dibagian badan dipisahkan dari kulit dan ruas-ruas tulang belakang atau duri yang menyatu dengan daging. Daging dibersihkan dan dipotong-potong dengan ukuran seperti dadu. Potongan daging kemudian diblender sampai homogen sehingga diperoleh homogenat. Homogenat dicampur dengan pakan tikus yang telah ditimbang sesuai kebutuhan untuk repeletting. Sebelum dicampur, ke dalam nampan yang berisi pakan tikus diberi air hangat dengan volume sesuai kebutuhan, lalu dihomogenisasi sampai diperoleh pakan yang kalis. Homogenat dari daging ikan gabus kemudian dicampurkan ke dalam pakan dengan konsentrasi sesuai yang dibutuhkan, berturut-turut $0 \%, 5 \%, 10 \%, 15 \%$, dan $20 \%$ dengan cara pakan pelet komersial sebanyak $12 \mathrm{~kg}$ direndam dalam air panas dengan suhu $100^{\circ} \mathrm{C}$ secukupnya. Pakan pelet komersial yang sudah tercampur dengan daging ikan gabus disesuaikan dengan perlakuan masing-masing dengan penambahan $150 \mathrm{~g}$ untuk P1 (5\%), $300 \mathrm{~g}$ untuk P2 (10\%), $450 \mathrm{~g}$ untuk P3 (15\%), dan $600 \mathrm{~g}$ untuk P4 (20\%). Pakan yang telah tercampur secara homogen kemudian dibuat pelet dengan menggunakan grinder. Pelet kemudian dikeringkan dengan menggunakan oven pada suhu $60^{\circ} \mathrm{C}$ selama 2 hari sehingga diperoleh kadar air kurang lebih $10 \%$.

Tikus putih Wistar diaklimasi dalam kandang individu yang diberi sekam dan tempat pakan. Selama proses aklimasi, tikus putih jantan diberi pakan pelet komersial yang berupa pelet
BR-2 dan minum secara ad-libitum. Proses aklimasi pada tikus Wistar dilakukan selama satu minggu. Tikus putih jantan akan dikondisikan mengalami stres dengan cara tidak diberi pakan selama satu minggu dan hanya diberikan minum secara ad-libitum yang diikuti dengan aktivitas berenang dalam air kran selama 10 menit dengan posisi ember tertutup.

Pakan pelet komersial BR2 yang telah ditambahkan daging ikan gabus diberikan pada hewan uji selama 14 hari berturut-turut, dimulai pada hari ke-8 sampai hari ke-21. Pemberian pakan yang disuplementasi dengan daging ikan gabus diberikan untuk setiap hewan uji secara $a d$ libitum. Selain itu, selama tahap perlakuan ini, tikus juga diberikan minum secara ad-libitum.

Seluruh tikus percobaan dikorbankan dengan cara dislokasi leher. Prosedur pembedahan tubuh tikus dilakukan dari aksis tubuh bagian posterior ke arah kolateral anterior. Organ hepar dipisahkan dari tubuh tikus melalui pemotongan dan dilanjutkan isolasi hepar. Organ hepar kemudian dimasukkan ke dalam garam fisiologis $(\mathrm{NaCl}$ 0,95\%), diletakkan pada tisu kering, dilanjutkan penimbangan dengan timbangan analitik dan kemudian disimpan dalam larutan fiksatif BNF $10 \%$ minimal 24 jam sebelum digunakan untuk pembuatan preparat histologi. Sediaan histologis hepar selanjutnya diproses dengan pewarnaan Hematoksilin-Eosin (HE). Perubahan histopatologi yang diamati berupa diameter vena sentralis dan hepatosit hepar.

Data yang diperoleh diuji pola distribusi dan homogenitasnya, dan dilanjutkan dengan uji Analysis of Variance (ANOVA) yang dilanjutkan dengan Duncant Multi Range Test (DMRT), masing-masing dengan signifikansi $5 \%$.

\section{HASIL DAN PEMBAHASAN}

\section{Pengaruh Suplementasi Daging Ikan Gabus (Channa striata) terhadap Diameter Hepatosit Hepar Tikus Wistar}

Hasil analisis pemberian suplemen daging ikan gabus dalam pakan terhadap diameter hepatosit tikus menunjukkan hasil yang berbeda nyata $(\mathrm{P}<0,05)$. Hasil uji lanjut dengan uji Duncan pada signifikansi $5 \%$ tidak terdapat beda nyata 
antara $\mathrm{P} 1$ dengan $\mathrm{P} 0$; $\mathrm{P} 2$ dengan $\mathrm{P} 0$; $\mathrm{P} 1$ dengan $\mathrm{P} 2$; P3 dengan P1; P3 dengan P2; terdapat beda nyata antara $\mathrm{P} 3$ dengan $\mathrm{P} 0$; $\mathrm{P} 4$ dengan $\mathrm{P} 0$; $\mathrm{P} 4$ dengan $\mathrm{P} 1$; P4 dengan P2; dan P3 dengan P3. Rata-rata pada perlakuan P3 dan P4 memiliki diameter hepatosit, masing-masing sebesar $11,1 \mu \mathrm{m}$ dan $12,3 \mu \mathrm{m}$ (Gambar 1).

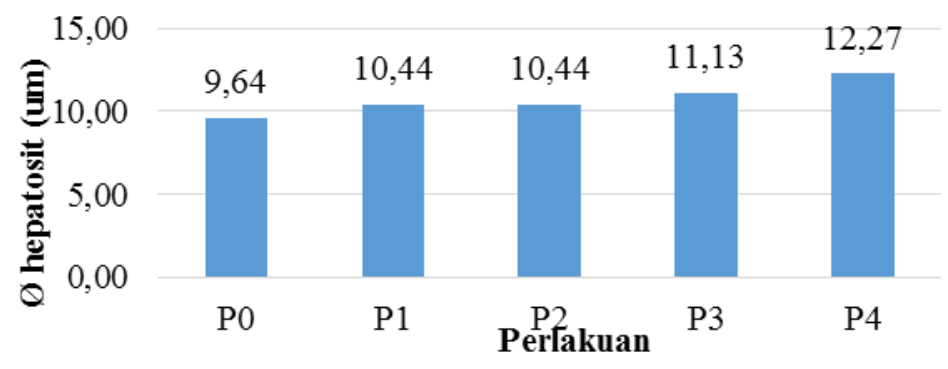

Gambar 1. Histogram diameter hepatosit hepar tikus Wistar yang mengalami stres fisiologis setelah pemberian pakan dengan suplementasi daging ikan gabus

Faktor yang menyebabkan nilai diameter hepatosit pada P3 lebih tinggi dibanding kontrol dan P4 lebih tinggi dibanding kontrol dan perlakuan lainnya karena perubahan metabolisme. Perubahan metabolisme tersebut ditandai dengan kebutuhan nutrisi pada saat pemulihan dari kondisi stres fisiologis yang semakin meningkat untuk mendukung keberlangsungan proses fisiologis, sehingga menyebabkan diameter hepatosit P3 lebih tinggi dibanding kontrol atau diameter hepatosit pada P4 lebih tinggi dibanding perlakuan lainnya. Ketersediaan substrat hasil suplementasi daging ikan gabus yang mengandung albumin, glutamin, sisten, dan glisin akan mendukung laju metabolisme pada P4 terjadi lebih cepat dibanding perlakuan lainnya sehingga volume hepatosit menjadi semakin meningkat. Volume hepatosit yang meningkat mempunyai korelasi dengan meningkatnya distribusi substrat ke jaringan tubuh terutama otot sehingga berpengaruh terhadap peningkatan produk metabolisme dan peningkatan bobot badan (Ningrum dan Abdulgani, 2014). Sebaliknya, ketika tidak terjadi perubahan metabolisme maka tidak akan terjadi perubahan diameter hepatosit, produk metabolisme dalam tubuh tidak berubah sehingga tidak terjadi peningkatan bobot badan tikus. Flaring et al. (2003) menyatakan bahwa ketersediaan protein albumin, glutamin, sistein, dan glisin dalam tubuh akan mendukung peningkatan diameter hepatosit, produk metabolisme, dan peningkatan bobot badan. Analisis histopatologi pada jaringan hepar ditunjukkan pada Gambar 2. Hasil pengamatan menunjukkan adanya perbedaan nyata diameter hepatosit hepar antara P4 dengan kontrol. Gambaran jaringan hepar pada kontrol dan semua perlakuan tampak normal dan tidak ditemukan sel yang mengalami degenerasi. Tidak ditemukan vakuolaisasi dalam hepatosit akibat adanya perlemakan atau pembengkakan sel akibat kelebihan air (swelling). Pengamatan terhadap hepatosit juga tidak ditemukan adanya piknosis, fragmentasi DNA, kondensasi kromatin maupun nekrosis.

Ningrum dan Abdulgani menyatakan, degenerasi sel-sel hepatosit ditandai dengan adanya piknosis, swelling atau pembengkakkan sel yang dipicu karena kelebihan air akibat sel kehilangan kontrol dalam regulasi air. Degenerasi hepatosit juga ditandai terjadinya ekspresi endonuklease yang menyebabkan terjadinya fragmentasi DNA yang diikuti kondensasi kromatin yang memicu apoptosis.

Pengaruh Suplementasi Daging Ikan Gabus (Channa striata) terhadap Diameter Vena Sentralis Hepar Tikus Wistar

Hasil analisis pemberian suplemen daging ikan gabus dalam pakan terhadap diameter vena sentralis hepar tikus menunjukkan hasil yang berbeda nyata $(\mathrm{P}<0,05)$. Hasil uji lanjut dengan uji Duncan pada signifikansi 5\% tidak terdapat beda nyata antara $\mathrm{P} 1$ dengan $\mathrm{P} 0 ; \mathrm{P} 2$ dengan $\mathrm{P} 0 ; \mathrm{P} 1$ 
dengan $\mathrm{P} 2$; namun terdapat beda nyata antara $\mathrm{P} 3$ dengan $\mathrm{P} 0 ; \mathrm{P} 3$ dengan $\mathrm{P} 1 ; \mathrm{P} 3$ dengan $\mathrm{P} 2 ; \mathrm{P} 4$ dengan $\mathrm{P} 0$; $\mathrm{P} 4$ dengan $\mathrm{P}$; $\mathrm{P} 4$ dengan $\mathrm{P}$ 2, namun $\mathrm{P} 4$ dengan $\mathrm{P} 3$ tidak berbeda nyata. Rata-rata pada perlakuan (P3 dan P4) memiliki diameter vena sentralis di atas dari nilai diameter vena sentralis tikus pada P0 (kontrol), P1, dan P2, yaitu sebesar $231,3 \mu \mathrm{m}$ dan $238 \mu \mathrm{m}$ (Gambar 3).
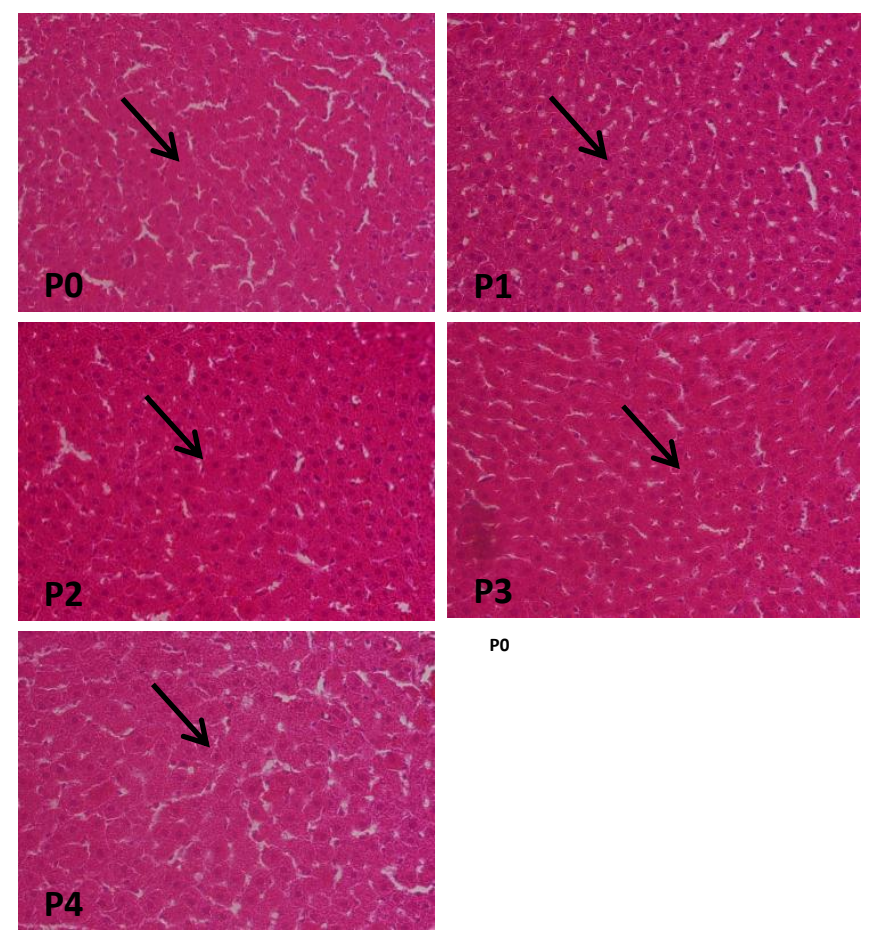

PO

Gambar 2. histopatologi hepatosit hepar tikus Wistar yang mengalami stres fisiologis setelah pemberian pakan dengan suplementasi daging ikan gabus. Pewarnaan menggunakan hematoksilin-eosin dan perbesaran 800x. P0: kontrol, P1: konsentrasi suplemen 5\%, P2: konsentrasi suplemen 10\%, P3: konsentrasi suplemen $15 \%$, P4: konsentrasi suplemen 20; anak panah menunjukkan hepatosit

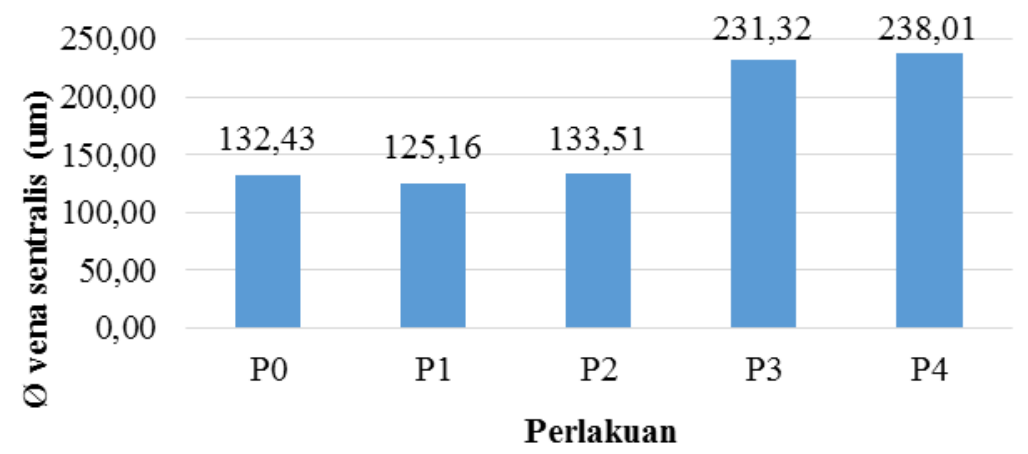

Gambar 3 Histogram diameter vena sentralis hepar tikus Wistar yang mengalami stres fisiologis setelah pemberian pakan dengan suplementasi daging ikan gabus

Faktor yang menyebabkan kondisi tersebut adalah perubahan metabolisme yang diindikasikan dengan adanya perubahan diameter hepatosit. Pemberian suplemen daging ikan gabus dalam pakan dengan konsentrasi yang tinggi (P3 dan $\mathrm{P} 4)$ akan meningkatkan diameter hepatosit. Peningkatan diameter sel ini akan memicu terjadi pertambahan diameter vena sentralis hepar. Diameter vena sentralis yang lebih lebar memungkinkan distribusi substrat metabolisme 
(albumin, glutamin, sistein dan glisin) ke jaringan tubuh terutama otot menjadi lebih banyak. Kondisi ini akan berpengaruh terhadap laju metabolisme dan produk metabolit serta energi di jaringan tubuh (otot) yang lebih besar yang akhirnya memberi pengaruh terhadap peningkatan bobot badan (Ningrum dan Abdulgani, 2014).

Gibson (2005) menyatakan, albumin, glutamin, sistein, dan glisin mempunyai peran penting pada perbaikan sel dan jaringan serta peningkatan bobot badan. Nugroho (2009) yang menyatakan bahwa penambahan ekstrak daging ikan gabus dapat meningkatkan kadar albumin, glutamin, sistein dan glisin dan bobot badan pada tikus Wistar. Yuniarti dkk., (2013) menyatakan bahwa protein albumin mempunyai peran penting dalam perbaikan jaringan. Schade et al. (2009) menyatakan, glutamin, sistein, dan glisin dapat meningkatkan sintesis asam nukleat dan protein serta memberi pengaruh anabolik yang dibutuhkan untuk mempercepat pemulihan kondisi fisiologis tubuh. Flaring et al. (2003) menyatakan, glutamin, sistein, dan glisin dapat menginduksi pengaruh anabolik seluler dengan meningkatkan volume sel, mengaktifkan protein kinase untuk menunjang metabolisme produk energi, meningkatkan proliferasi sel, mempercepat perbaikan jaringan dan peningkatan bobot badan. Analisis histopatologi (vena sentralis) jaringan hepar ditunjukkan pada Gambar 4 Hasil pengamatan menunjukkan adanya perbedaan nyata diameter vena sentralis hepar antara P4 dengan kontrol. Gambaran vena sentralis hepar pada kontrol dan semua perlakuan tampak normal, tidak ditemukan kerusakan pada vena sentralis dan tidak ditemukan sel-sel endotel pada vena sentralis yang mengalami degenerasi. Menurut Price and Lorraine (2006) kerusakan pada vena sentralis berupa lisisnya sel endotelium sehingga lingkaran menjadi tidak utuh dan akhirnya lingkaran menjadi tidak jelas.

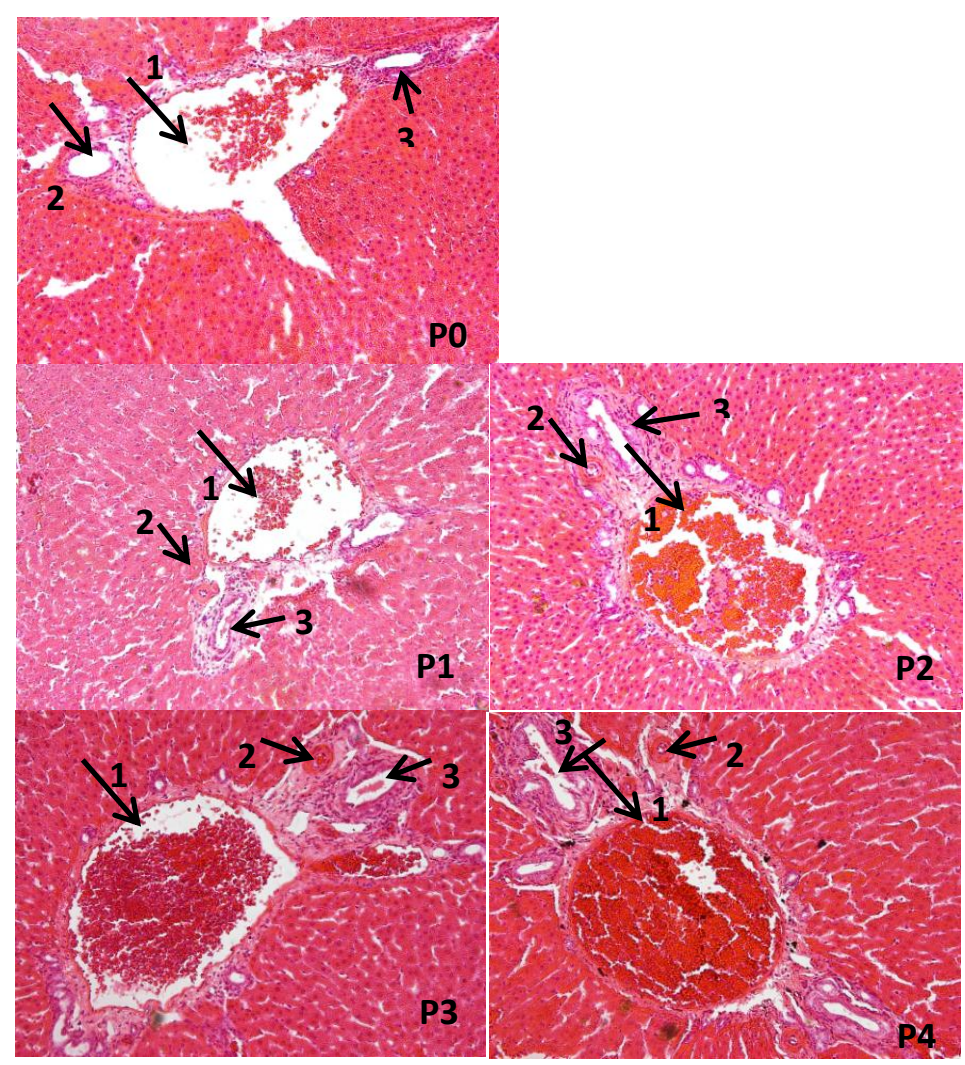

Gambar 4. Histopatologi vena sentralis hepar tikus Wistar yang mengalami stres fisiologis setelah pemberian pakan dengan suplementasi daging ikan gabus. Pewarnaan menggunakan hematoksilin-eosin dan perbesaran 400x. P0: kontrol, P1: konsentrasi suplemen 5\%, P2: konsentrasi suplemen 10\%, P3: 
konsentrasi suplemen 15\%, P4: konsentrasi suplemen 20; anak panah 1. menunjukkan vena sentralis,

2. Arteri hepatika, 3. Vena porta

Peningkatan diameter vena sentralis dan hepatosit pada perlakuan P4 merupakan indikasi peningkatan volume sel setelah perlakuan pakan dengan suplementasi daging ikan gabus dan peningkatan tersebut bukan degenerasi. Faktor yang menyebabkan peningkatan tersebut diduga berkaitan dengan perlakuan suplemen daging ikan gabus dengan konsentrasi 20\%. Perlakuan suplemen daging ikan gabus dengan konsentrasi yang tinggi akan menyebabkan ketersediaan albumin, glutamin, sistein, dan glisin dalam plasma menjadi meningkat. Meningkatnya protein dan beberapa jenis asam amino ini akan menyebabkan ketersediaan protein dan senyawa intraseluler menjadi lebih meningkat yang akhirnya berpengaruh terhadap peningkatan volume sel. Schade et al. (2009) dan Flaring et al (2003) menyatakan bahwa protein albumin, glutamin, sistein, dan glisin dapat meningkatkan volume sel dan bobot jaringan. Lebih lanjut dinyatakan bahwa albumin, glutamin, sistein dan glisin mempunyai keterkaitan dengan proses anabolik (sintesis asam nukleat dan protein), terlibat dalam pemulihan kondisi fisiologis pasca stres, perbaikan sel atau jaringan serta peningkatan volume dan integritas seluler (Dringen et al., 2000; Roth et al., 2008).

Sel dan jaringan hepar merupakan jaringan yang memiliki kemampuan untuk mempertahankan integritas seluler dari pengaruh radikal bebas dan rantai reaksi radikal bebas yang terbentuk selama berlangsungnya stres fisiologis (Andreas et al., 2015). Stres fisiologis yang tidak lama seperti pada penelitian memungkinkan sistem dalam tubuh lebih spesifik lagi pada hepar dapat menetralisir dampak gangguan dan kerusakan yang dipicu oleh stres fisiologis yang bersifat sementara. Sistem yang ada dalam jaringan hepar dimungkinkan dapat mencegah dampak dari stres fisiologis tersebut. Lebih lanjut dinyatakan bahwa hepar memiliki sistem enzimatis dan non enzimatis untuk menetralisir atau menonaktifkan radikal bebas atau rantai reaksi radikal bebas yang melibatkan aktivitas beberapa enzim, antara lain superoksida dismutase, glutation, dan katalase. Akhirnya stres fisiologis tidak memicu terjadinya kerusakan atau degenerasi sel atau jaringan hepar seperti dijelaskan pada bukti-bukti dari penelitian ini.

\section{UCAPAN TERIMA KASIH}

Penulis mengucapkan terima kasih kepada Direktorat Jenderal Pendidikan Tinggi (Dirjen Dikti) Departemen Pendidikan Nasional yang telah memberi dana penelitian untuk pendanaan Hibah Fundamental Tahap II melalui Dana Operasional Perguruan Tinggi (BOPTN) Universitas Diponegoro tahun 2015 sehingga penelitian dan penulisan artikel ini dapat diselesaikan.

\section{KESIMPULAN}

Berdasarkan hasil penelitian ini dapat disimpulkan bahwa pemberian pakan dengan suplementasi daging ikan gabus dapat meningkatkan bobot badan, bobot hepar, diameter vena sentralis dan hepatosit hepar pada tikus Wistar yang mengalami stres fisiologis.

\section{DAFTAR PUSTAKA}

Aisyatussofi, N dan Abdulghani, N. 2013. Pengaruh Pemberian Ekstrak Ikan Gabus (Channia striata) pada Struktur Histologi Pankreas dan Kadar Glukosa Darah Mencit (Mus musculus) Hiperglikemik. J. Sains dan Seni Pomits 2(1): 2337-3520.

Andreas, H., Trianto, H. F dan M. I. Ilmiawan. 2015. Gambaran Histologi Regenerasi Hati Pasca Penghentian Pajanan Monosodium Glutamat pada Tikus Wistar. Skripsi. Fakultas Kedokteran Universitas Tanjungpura, Pontianak.

Charlton, M. 2006. Branched-Chain Amino Acid Enriched Supplements as Therapy for Liver Disease. The Journal of Nutrition., 12(12): 295S-298S

Chotechuang, N. 2010. The Role of Amino Acids in Liver Protein Metabolism under a High Protein Diet: Identification of Amino Acids Signal and Associated Transduction Pathways. AgroParisTech, UMR914 
Nutrition Physiology and Ingestive Behaviour, F-75005 Paris.

Dringen, R., J. M. Gutterer and J. Hirrlinger. 2000. Glutathione Metabolism in Brain: Metabolic Interaction Between Astrocytes and Neurons in The Defense Against Reactive Oxygen Species. Eur. J. Biochem 267: 4912-4916

Flaring, U. B., O. E. Rooyackers, J. Wernerman and F. Hammarqvist. 2003. Glutamine Attenuates Post-traumatic Glutathione Depletion in Human Muscle. Clin Sci 104: 275-82

Gibson S. 2005. Principles of Nutritional Assesment, Published by oxford University. Prees.nc.198 Madison Avenue. New York.

Ningrum, D. W. L dan Abdulgani. 2014. Pengaruh Pemberian Ekstrak Ikan Gabus (Channia striata) pada Struktur Histologi Hati Mencit (Mus musculus) Hiperglikemik. J. Sains dan Seni Pomits 2(1): 2337-3520

Nugroho, M. 2009. Uji Biologis Ekstrak Kasar dan Isolat Albumin Ikan Gabus (Ophiocephalus striatus) Terhadap Berat Badan dan Kadar Serum Albumin Tikus Mencit. Jurnal Saintek Perikanan 9 (1): 49-54.

Roth, E. 2008. Nonnutritive Effects of Glutamine. J. Nutr. 138: 2025S-2031S.

Schade, R. S. M, M. Grundling, D. Pavlovic, K. Starke, M. Wendt, S. Retter, M. Murphy, U. Suchner, A. Spassov, T. Gedrange and
C. H. Lehmann. 2009. Glutamine and Alanyl-Glutamine Dipeptide Reduce Mesenteric Plasma Extravasation, Leucocyte Adhesion and Tumor Necrosis Factor-Alpha. Journal of Physiology and Pharmacology 60 (8): 19-24.

Silva, M., Gomes, S., Peixoto, A., Ramalho, P. T., Cardoso, H., Azevedo, R., Cunha, C and G. Macedo. 2015. Nutrition in Chronic Liver Disease. GE Port J Gastroenterol., 22(16): 268-276

Suarsana, I. N., Wresdiyati, T dan A. Suprayogi. 2013. Respon Stres Oksidatif dan Pemberian Isoflavon terhadap Aktivitas Enzim Superoksida Dismutase dan Peroksidasi Lipid pada Hati Tikus. JITV 18(2): 146-152.

Sunarno, Manalu, W., Kusumorini, N and D. R. Agungpriyono. 2013. Perbaikan Respons Seluler pada Penuaan Hipokampus yang Diperantarai Glutation Hasil Pemberian Alanin-glutamin Dipeptida. J. Vet., 14(1): 61-71

Sunarno, S. M. Mardiati dan T. Suprihatin. 2015. Potensi Bahan Antiaging dari Ekstrak Ikan Gabus (Channa striata) terhadap Perbaikan Histo-Morfologi Hipokampus. Buletin Anatomi dan Fisiologi 2015: 1-8.

Yuniarti, D. W., Sulistiyani, T. D dan E. Suprayitno. 2013. Pengaruh Suhu Pengeringan Vakum Terhadap Kualitas Serbuk Albumin Ikan Gabus (Ophiocephalus striatus). THPi Student $\begin{array}{lll}\text { Journal } & 1 & \text { (1): }\end{array}$ 